нения окраинных морей северо-западной части Тихого океана // Океанология. 2006. Т. 46, № 1. С. 55-62.

11. Галышева Ю.А. Биологические последствия органического загрязнения прибрежных морских экосистем российской части Японского моря // Известия ТИНРО. 2009. Т. 158. С. 209-227.

12. Христофорова Н.К., Журавель Е.В., Миронова Ю.А. Рекреационное воздействие на залив Восток (Японское море) // Биология моря. 2002. Т. 28, № 4. C. $300-303$.

13. Бойченко Т.В. Химико-экологическая и микробиологическая оценка качества морских поверхностных вод Южного Приморья: дис. ... канд. биол. наук. Владивосток, 2009. 150 с.

14. Галышева Ю.А., Христофорова Н.К. Среда и макробентос залива Восток Японского моря в условиях рекреационного воздействия // Известия ТИНРО. 2007. Т. 149. С. 270-309.

15. Журавель Е.В., Христофорова Н.К., Дроздовская О.А., Токарчук Т.Н. Оценка состояния вод залива Восток (залив Петра Великого, Японское море) по Разнообразие культивируемых гетеротрофных бактерий..

гидрохимическим и микробиологическим показателям // Водные ресурсы. 2012. Т. 14, № 1 (9). С. 2315-2329.

16. Youchimizu M., Kimura T. Study of intestinal microflora of Salmonids // Fish. Pathol. 1976. Vol. 10, № 2. Р. 243 .

17. Винникова О.И., Самойлов А.М., Попова Ю.В. Выделение и идентификация бактерий: методические рекомендации для студентов биол. факультета специализации «Микробиология и вирусология». Харьков: ХНУ имени В.Н. Каразина, 2011. 60 с.

18. Хоулт Дж., Криг Н., Смит П. Определитель бактерий Берджи в 2-х томах: Т. 1, Т. 2. М.: Изд-во Мир. 1997. 800 с.

19. СанПиН 4631-88 «Санитарные правила и нормы охраны прибрежных вод морей от загрязнения в местах водопользования населения».

Работа выполнена при финансовой поддержке Российского научного фонда (Соглашение № 1450-00034).

\title{
DIVERSITY OF CULTIVATED HETEROTROPHIC BACTERIA SELECTED FROM SURFACE WATERS OF THE VOSTOK BAY OF THE JAPANESE SEA
}

(C) 2017

Golozubova Julia Sergeevna, postgraduate student of Ecology Department

Buzoleva Lyubov Stepanovna, doctor of biological sciences, professor, professor of Biodiversity and Marine Bioresources Department

Bogatyrenko Elena Aleksandrovna, candidate of biological sciences, associate professor of Biodiversity and Marine Bioresources Department

Kim Alexandra Vyacheslavovna, postgraduate student of Ecology Department

Eskova Alena Igorevna, postgraduate student of Biodiversity and Marine Bioresources Department Far Eastern Federal University (Vladivostok, Russian Federation)

Abstract. In this article, the taxonomic diversity of cultivated heterotrophic microorganisms of the surface waters of Bay Vostok of Peter the Great Bay of the Japan Sea was considered. In the bay Vostok total number of heterotrophic microorganisms was $2,03-10^{5} \mathrm{KOE} / \mathrm{ml}$ which can be attributed to mezazoprobnye sea water. Microorganisms isolated from this coastal area are represented by 4 phylums. The cultivated microorganisms were dominated by representatives of the phylum Proteobacteria, which accounted for more than $50 \%$ of the total taxonomic diversity of the cultivated bacteria of the Vostok Bay. Phylums of Bacteroidetes, Firmicutes and Actinobacteria were also isolated. The taxonomic diversity of microbial community was represented by 15 genus. Based on the phenotypic characteristics, cultured heterotrophic bacteria was classified into the genera Rhodococcus sp., Micrococcus sp., Actynomycetes sp., Bacillus sp., Sarcina sp., Pseudomonas sp., Acinetobacter sp., Arthrobacter sp., Vibrio sp., Halomonas sp., Flavobacterium sp., Acetobacter sp., and Marinococcus sp., Pseudoalteromonas sp., Aeromonas sp., Staphylococcus sp. Sanitation-indicative bacteria in this bay were not identified, which indicates a slight anthropogenic impact. Thus bay Vostok was really insignificant recreational stress and it was reflected on marine microbial community.

Keywords: cultured heterotrophic microorganisms; taxonomic composition; community; anthropogenic pollution; marine microorganisms; ecological monitoring; Sea of Japan; Gulf of Peter Great; Vostok bay; sanitary-demonstration microorganisms.

УДК 581.93

Статья поступила в редакцию 28.08.2017

\section{ФЛОРА СТУДЕНЧЕСКОГО СКВЕРА ГОРОДА ЧЕБОКСАРЫ ЧУВАШСКОЙ РЕСПУБЛИКИ} (C) 2017

Димитриев Юрий Олегович, кандидат биологических наук, доцент кафедры биоэкологии и химии Чувашский государственный педагогический университет им. И.Я. Яковлева

(г. Чебоксары, Российская Федераџия)

Аннотащия. Студенческий сквер был открыт 1 сентября 2007 г. на пересечении оживлённого Московского проспекта и улицы К. Иванова. Общая площадь 2,5 га. Преобладающими древесными породами являются Tilia cordata Mill., Betula pendula Roth и Acer platanoides L. В 2016 г. была проведена первая инвентаризация флоры сквера, выявлено 94 вида растений из 79 родов и 37 семейств. Хвойные представлены 4 культивируемыми интродуцентами. К однодольным относится только 6 видов из семейства Роасеае. Систематическое разнообразие флоры очень низкое. Практически каждый род представлен лишь одним видом. Средний уро- 
вень видового богатства в одном семействе - 2,54. Число семейств с одним видом - 21 (56,8\%). Десять ведущих по числу видов семейств концентрируют 63,8\% видов. Спектр ведущих семейств флоры Студенческого сквера указывает на её термофильный облик. Доля синантропных видов во флоре в целом - 53,2\%. Индекс синантропизации (Is) флоры сквера составляет 1,14 и подчёркивает антропогенный характер ландшафта. Аборигенная фракция флоры сильно изменена $(I s=0,48)$. В эколого-ценотическом спектре наблюдается перевес в сторону растений открытых типов местообитаний, причём среди них преобладают сорные виды (34\%), среди которых отмечены 4 злостных инвазионных вида: Acer negundo L., Conyza canadensis (L.) Cronq., Lepidotheca suaveolens (Pursh) Nutt., Xanthoxalis stricta (L.) Small. На втором месте расположена группа луговых растений (16\%). Распределение других ценотических групп в целом согласуется с региональным спектром флоры Чувашии. В спектре гигроморф преобладают мезофиты (71,3\%), далее следуют ксеромезофиты (16\%), доля остальных групп колеблется от 1,1 до 6,4\%. В спектре трофоморф преобладают мезотрофы $(62,8 \%)$ и мегатрофы (36,2\%). Адвентивная фракция составляет 30,9\% флоры сквера. 17 видов (58,6\%) являются культивируемыми интродуцентами, а остальные - сорными растениями. Преобладают кенофиты $(75,9 \%)$, эргазиофиты и эргазиофигофиты (по 24,1\%), эпекофиты и агрио-эпекофиты $(65,5 \%)$, североамериканские $(31 \%)$ и ирано-туранские $(20,7 \%)$ виды.

Ключевые слова: флора; сквер; озеленение; Чебоксары; Чувашская Республика; комфортная городская среда; экологическая оценка; таксономический анализ; синантропизация; эколого-ценотический спектр; инвазионные растения; гигроморфы; трофоморфы; адвентивные растения; флорогенетический анализ.

\section{Введение}

Основу озеленения городской среды составляют насаждения общего пользования. Из них скверам уделяется особое внимание, так как, представляя собой компактные озеленённые территории площадью от 0,5 до 2,5 га, они легко могут быть размещены на городских площадях, пересечениях улиц, у административных и общественных зданий, что даёт возможность значительно улучшить санитарно-гигиенические показатели атмосферного воздуха и внести разнообразие в отдых горожан. Так, согласно данным с официального сайта МБУ «Управление экологии города Чебоксары», количественно среди озеленённых территорий общего пользования в пределах городского округа преобладают скверы - 89 объектов $(75,4 \%)$, что демонстрирует их большой удельный вес в озеленении города.

С 2017 года Чебоксары, как и многие российские города, стали участником федерального проекта «Формирование комфортной городской среды», одним из направлений которого является повышение уровня благоустройства общественных территорий города (парков, скверов и т.д.), «включающего в себя ремонт тротуаров, установку скамеек и урн, обеспечение освещения, оборудование автомобильных (гостевых) парковок» [1]. Данные виды работ, безусловно, важны ввиду того, что «доминирующим видом использования скверов является кратковременный отдых и транзитное движение пешеходов» [2]. Однако на стадии составления проекта по благоустройству парков и скверов необходимо принимать во внимание видовое разнообразие и состояние зелёных насаждений, так как именно они определяют функциональное назначение и эстетический облик озеленённых территорий. К тому же, «городские скверы испытывают постоянное воздействие транспортной и инженерной инфраструктур», «видовой состав растительности скверов не всегда отвечает сложившимся условиям» и «представлен ограниченным числом видов» [2].

Анализ публикаций последних лет, посвященных изучению и оценке зелёных насаждений скверов, подтверждает эту мысль. Например, А.И. Репецкая и И.А. Парфенова, проводя оценку территории, на которой запланировано создание сквера 70-летия Великой Отечественной войны (г. Севастополь), анализируют таксономический состав и экологическое со- стояние имеющихся зеленых насаждений, на основании чего предлагают проектные решения по созданию нового ландшафтного объекта с использованием перспективного для региона ассортимента древеснокустарниковых пород [3]. Инвентаризации дендрофлоры скверов Дзержинского и Мотовилихинского районов г. Перми посвящена работа Н.А. Молгановой и С.А. Овеснова, по результатам которой был зарегистрирован 121 вид и гибридогенный таксон из 50 родов и 18 семейств; в то же время ими отмечается небольшое видовое разнообразие (менее 20 видов) у половины обследованных скверов [4]. При оценке состояния древесно-кустарниковых форм скверов г. Рязани также заполнялись геоботанические описания и ведомости описания деревьев; авторы отмечают, что «на состояние насаждений этой категории наиболее существенное влияние оказывают повышенные рекреационные нагрузки, стихийно проложенные пешеходные тропы, скопления мусора и другие негативные факторы» [5]. Анализ современного состояния различных скверов г. Ростова-на-Дону тоже основан на исследовании их флоры, причём обследовались не только древесно-кустарниковые насаждения с определением основных видов болезней и вредителей, но и была «дана оценка цветочного оформления, газонного покрытия и благоустройства скверов» [6]. Таким образом, принятие грамотных управленческих решений по формированию комфортной городской среды должно базироваться на данных систематического мониторинга за объектами озеленения, который в том числе подразумевает проведение регулярных флористических исследований, так как «список флоры несет существенную экологическую информацию о состоянии экосистем» [7].

«Территория Чебоксар в флористическом отношении практически не изучена» [7], а сведения о дендрофлоре объектов озеленения общего пользования содержатся лишь в их паспортах, составленных специалистами Управления экологии г. Чебоксары в 2000-е годы. Систематические исследования флоры скверов г. Чебоксары были начаты автором с 2014 г. с участием студентов-дипломников кафедры биоэкологии и химии ЧГПУ им. И.Я. Яковлева [8-12].

Целью настоящей статьи является комплексный анализ флоры Студенческого сквера и выработка практических рекомендаций по улучшению его экологического состояния. 
Димитриев Ю.О.

Объект, результаты исследования и их обсуждение

Инвентаризация флоры Студенческого сквера проводилась в полевой сезон 2016 г. Для более полного учёта растений использовался маршрутно-экскурсионный метод в сочетании с геоботаническим описанием пробных площадок и цветников. Виды определялись по «Флоре ...» П.Ф. Маевского [13].

Сквер Студенческий расположен в Московском районе города Чебоксары напротив главного корпуса Чувашского государственного университета имени И.Н. Ульянова на пересечении оживлённого Московского проспекта и улицы К. Иванова. 1 сентября 2017 г. исполнилось 10 лет со дня его открытия. Согласно паспорту объекта, сквер предназначен для отдыха, прогулок, транзитного движения пешеходов, художественно-декоративного оформления территории города. Общая площадь Студенческого сквера 2,5 га, из них 1,68 га составляют газоны, 275,58 м²цветники. Преобладающими древесными породами являются Tilia cordata Mill., Betula pendula Roth и Acer platanoides L. Сквер имеет форму прямоугольного треугольника, в восточной части которого размещены уличные спортивные тренажёры и игровой комплекс для детей. Главным украшением сквера является скульптура «Добрый ангел мира» - дань памяти и глубокого уважения великим меценатам минувших дней, - установленная по инициативе Международного Благотворительного фонда «Меценаты столетия».

Флора Студенческого сквера насчитывает 94 вида из 79 родов и 37 семейств (табл. 1). Хвойные представлены четырьмя культивируемыми интродуцентами: Larix decidua Mill., Picea abies (L.) Karst. и Picea pungens Engelm., Thuja occidentalis L. Из 90 видов цветковых растений к однодольным относится только 6 видов $(6,7 \%)$ из семейства Poaceae: Bromopsis inermis (Leyss.) Holub, Dactylis glomerata L., Phleum pratense L., Poa nemoralis L., Poa апnиa L., Elytrigia repens (L.) Nevski. Малая доля однодольных растений, являющихся преимущественно гидро- и гигрофильными видами, как и отсутствие сосудистых споровых растений в составе флоры является свидетельством высокого техногенного влияния (соседство с транспортными магистралями с высокой интенсивностью движения автомобилей) и значительной рекреационной нагрузки на экосистемы сквера.

Таблица 1 - Основные параметры флоры Студенческого сквера

\begin{tabular}{|c|c|c|c|c|c|c|c|c|c|c|}
\hline \multirow[b]{2}{*}{ Флора } & \multicolumn{3}{|c|}{ Число таксонов } & \multicolumn{3}{|c|}{ Пропорции флоры } & \multirow{2}{*}{$\begin{array}{c}\text { Доля } \\
\text { однодольных } \\
\text { среди } \\
\text { цветковых, \% }\end{array}$} & \multirow[b]{2}{*}{$\begin{array}{c}\text { Доля видов } \\
\text { в } 10 \text { ведущих } \\
\text { семействах, \% }\end{array}$} & \multirow{2}{*}{$\begin{array}{c}\text { Соотноше- } \\
\text { ние } \\
\text { Asteraceae / } \\
\text { Poaceae }\end{array}$} & \multirow{2}{*}{\begin{tabular}{|c|} 
Индекс \\
синан- \\
тропи- \\
зации Is
\end{tabular}} \\
\hline & $\begin{array}{l}\text { Ви- } \\
\text { ды }\end{array}$ & $\begin{array}{l}\text { Po- } \\
\text { ды }\end{array}$ & $\begin{array}{l}\text { Се- } \\
\text { мей- } \\
\text { ства }\end{array}$ & $\mathrm{B} / \mathrm{C}$ & $\mathrm{B} / \mathrm{P}$ & $\mathrm{P} / \mathrm{C}$ & & & & \\
\hline Аборигенная & 65 & 56 & 27 & 2,41 & 1,16 & 2,07 & 9,2 & 70,8 & 2,3 & 0,48 \\
\hline Адвентивная & 29 & 28 & 18 & 1,61 & 1,04 & 1,56 & 0 & 72,4 & - & - \\
\hline В целом & 94 & 79 & 37 & 2,54 & 1,19 & 2,14 & 6,7 & 63,8 & 3 & 1,14 \\
\hline
\end{tabular}

Систематическое разнообразие флоры очень низкое. Практически каждый род представлен лишь одним видом. Средний уровень видового богатства в одном семействе составляет 2,54. Всего 11 семейств содержат 3 и более видов, насчитывая в общем 63 вида (67\%). Число семейств с одним видом $21(56,8 \%)$.

Усиление роли ведущих семейств и значительное концентрирование видов в них свидетельствует о высокой специфичности и экстремальности экологических условий, что приводит к выпадению видов и родов, не адаптированных к условиям городской среды. Согласно В.А. Шадрину, в естественных синантропизированных флорах на 10 ведущих семейств приходится 60-69\% видов, в антропогенно трансформированных сегетальных, рудеральных флорах и в адвентивных фракциях - 70\% и более [14]. Как следует из табл. 1, флору сквера в целом можно охарактеризовать как естественную синантропизированную, но если рассматривать отдельно природное ядро флоры, то оно будет уже антропогенно трансформированным. Доля синантропных видов во флоре в целом - 53,2\%, причём из них больше половины приходится на сорные виды и лишь одна треть видов - на культивируемые интродуценты. Но если использовать в качестве индикатора индекс синантропизации Is (соотношение синантропных и несинантропных видов) [14], более чётко отражающий величину антропогенного прессинга, то видно, что территория сквера представляет собой типичный антропогенный ландшафт $(I s=1,14)$, а аборигенная флора сильно изменена $(I s=0,48)$.
Первые позиции в десяти ведущих семействах флоры Чувашии занимают Asteraceae, Poaceae, Rosaceae, Cyperaceae, Brassicaceae, Fabaceae [15]. Во флоре Студенческого сквера тоже преобладают эти семейства, но с некоторыми перестановками, а также за исключением отсутствующего семейства Cyperaceae (табл. 2). Так семейство Rosaceae смещается на второе место, что объясняется наличием культивируемых интродуцентов из этого таксона: Cotoneaster horizontalis Decne., Pentaphylloides fruticosa (L.) Schwarz, Sorbaria sorbifolia (L.) A.Br., Spiraea media Schmidt, Malus baccata (L.) Borkh. Семейство Fabaceae, характерное для более южных регионов [15, c. $262 ; 16]$, перемещается во флоре сквера на третью позицию, отражая, видимо, ослабление зональных черт и их смещение в термоксерическом направлении. «Общеизвестно, что при продвижении с севера на юг возрастает роль термофильных семейств, таких как Lamiaceae, Scrophulariaceae, Boraginaceae и других», а в урбанофлорах Восточной Европы (в сравнении с региональными флорами) «возрастает доля семейств Chenopodiaceae, Polygonaceae» [16]. Таким образом, спектр ведущих семейств флоры Студенческого сквера согласуется с тенденцией развития урбанофлор, указывая на её термофильный облик.

Поскольку действие антропогенных факторов приводит к изменению экологических условий развития флоры, всё это находит отражение в распределении растений по эколого-ценотическим группам. Под эколого-ценотическими группами понимались «группы видов растений, сходных по отношению к 
совокупности экологических факторов, присущих биотопам того или иного типа, характеризующихся высокой степенью взаимной сопряженности и приуроченных к микроместообитаниям определенного типа» $[17$, с. 170$]$. С учетом ценотических особенностей урбанофлоры была выделена особая группа «виды культурценозов», включающая культивируемые интродуценты [18], так как «в некоторых формах городского зелёного покрова, например в парках... интродуценты играют важную роль в сложении растительного покрова и в выполнении им своих основных функций» [19].

Таблица 2 - Ведущие семейства флоры Студенческого сквера

\begin{tabular}{|l|c|c|c|c|c|c|c|c|c|}
\hline \multirow{2}{*}{ Флора } & \multicolumn{7}{c|}{ Ранг ведущих семейств } \\
\cline { 2 - 9 } & 1 & 2 & 3 & 4 & 5 & 6 & 8 & 9 & 10 \\
\hline В целом & $\mathrm{As}^{18}$ & $\mathrm{Ro}^{9}$ & $\mathrm{Fa}^{7}$ & $\mathrm{Po}^{6}$ & $\mathrm{Br}^{4}, \mathrm{Pol}^{4}$ & \multicolumn{4}{c|}{$\mathrm{Ch}^{3}, \mathrm{Sc}^{3}, \mathrm{Lam}^{3}, \mathrm{Plant}^{3}$} \\
\hline Аборигенная & $\mathrm{As}^{14}$ & \multicolumn{2}{|c|}{$\mathrm{Fa}^{6}, \mathrm{Po}^{6}$} & $\mathrm{Ro}^{4}$ & \multicolumn{2}{c|}{$\mathrm{Pol}^{3}, \mathrm{Ch}^{3}, \mathrm{Lam}^{3}, \mathrm{Plant}^{3}$} & $\mathrm{Ap}^{2}, \mathrm{Sc}^{2}$ \\
\hline Адвентивная & $\mathrm{Ro}^{5}$ & $\mathrm{As}^{4}$ & \multicolumn{2}{|c|}{$\mathrm{Br}^{3}, \mathrm{Pin}^{3}$} & \multicolumn{4}{|c|}{$\mathrm{Fa}^{1}, \mathrm{Am}^{1}, \mathrm{Pol}^{1}, \mathrm{Sc}^{1}, \mathrm{Ran}^{1}, \mathrm{Ber}^{1}$} \\
\hline
\end{tabular}

Примечание. Am - Amaranthaceae, $\mathrm{Ap}$ - Apiaceae, $\mathrm{As}$ - Asteraceae, $\mathrm{Ber}$ - Berberidaceae, $\mathrm{Br}$ - Brassicaceae, $\mathrm{Ch}$ - Chenopodiaceae, Fa - Fabaceae, Lam - Lamiaceae, Pin - Pinaceae, Plant - Plantaginaceae, Po - Poaceae, Pol Polygonaceae, Ran - Ranunculaceae, Ro - Rosaceae, Sc - Scrophulariaceae. Число видов в семействе указано знаком степени.

Если в фитоценотическом спектре флоры Чувашии преобладают лесные виды $(17,3 \%)$, затем следуют луговые $(14,7 \%)$, лугово-лесные и опушечные $(16,4 \%)$, остепнённых лугов и склонов $(9,6 \%)$, степные и лугово-степные $(8,7 \%)$, прибрежно-водные $(4,1 \%)$ и т.д. $[15$, с. 266$]$, то во флоре сквера наблюдается перевес в сторону растений открытых типов местообитаний, причём среди них значимая роль принадлежит сорным видам, занимающим первое место более чем с двукратным отрывом (табл. 3). Следует заметить, что подобные эколого-ценотические спектры характерны для большинства урбанофлор [16].

Таблица 3 - Эколого-ценотические группы растений во флоре Студенческого сквера

\begin{tabular}{|c|l|c|}
\hline № п/п & \multicolumn{1}{|c|}{ Фитоценогруппы } & Доля видов, \% \\
\hline \multirow{2}{*}{1} & Сорные, & 34,0 \\
& в т.ч. рудеральные & 29,8 \\
\hline 2 & Луговые & 16,0 \\
\hline 3 & Лесные & 14,9 \\
\hline 4 & Виды культурценозов & 12,8 \\
\hline 5 & Лугово-лесные и опушечные & 10,6 \\
\hline 6 & Лесостепные & 4,3 \\
\hline 7 & Степные и лугово-степные & 4,3 \\
\hline 8 & Прибрежно-водные & 3,2 \\
\hline
\end{tabular}

Наибольшее число сорных видов - из семейства Asteraceae (10 видов), в остальных 17 семействах от 1 до 3 сорных вида. Из 32 сорных видов 18 видов относятся к аборигенной фракции, а 14 - к адвентивной. Среди последних стоит выделить злостные инвазионные виды, занесённые в «Чёрную книгу флоры Средней России» [20]: Acer negundo L., Conyza canadensis (L.) Cronq., Lepidotheca suaveolens (Pursh) Nutt., Xanthoxalis stricta (L.) Small. В сквере произрастают еще два вида, указанные в «Чёрной книге...», но нами они отнесены к видам культурценозов, так как не проявляют агрессивную инвазию, хотя, безусловно, дичают - это Fraxinus pennsylvanica Marsh. (по степени натурализации является эпекофитом [15]) и Sorbaria sorbifolia (L.) A.Br. (эфемерофит). Значительная доля сорных видов во флоре сквера (а отдельно в травяном покрове их содержание составляет $41,7 \%$ ) соответствует условиям произрастания на нестабильных антропогенных или нарушенных местообитаниях.
Вторую позицию занимает луговой флороценотип, что связано с наличием открытых пространств в центральной части сквера. Распределение других ценотических групп вполне логично для сквера и в целом согласуется с региональным спектром флоры Чувашии.

Для экологической оценки территории Студенческого сквера были определены отношения видов к влиянию прямодействующих экологических факторов, наиболее важных для высших сосудистых растений, а именно: водному и трофическому режиму почв. В соответствии с системой гигроморф и трофоморф А.Л. Бельгарда (в модификации Н.М. Матвеева [21]) были составлены соответствующие экологические спектры. В спектре гигроморф преобладают мезофиты (71,3\%), что свойственно флорам умеренной зоны и подтверждает бореальные черты исследуемой флоры. На втором месте находятся ксеромезофиты (16\%), что связано как с положением сквера в верхней части местного водораздела рек Волга и Чебоксарка, так и с уплотнённостью почвы, приводящими к некоторому дефициту влаги. Доля остальных групп колеблется от 1,1 до 6,4\%: гигромезофиты - 6,4\%, ксерофиты - 3,2\%, мезоксерофиты $2,1 \%$, гигрофиты - 1,1\%. Влаголюбивые виды представлены исключительно аборигенными растениями: Lysimachia nummularia L., Potentilla anserina L., Prunella vulgaris L., Rorippa palustris (L.) Bess., Rumex confertus Willd., Stellaria media (L.) Vill., Tussilago farfara L. Таким образом, для исследуемого сквера свойственен свежий гигротоп (свежий тип увлажнения почвы) [8].

В спектре трофоморф преобладают мезотрофы (62,8\%) и мегатрофы (36,2\%). Олиготрофы представлены лишь одним видом - Betula pendula Roth. Следовательно, для сквера характерны среднеплодородные и плодородные почвы [8]. Полученные спектры гигроморф и трофоморф флоры Студенческого сквера практически совпадают с эдафотопической структурой флоры сквера им. М. Горького г. Чебоксары, также расположенного на водоразделе рек Волга и Чебоксарка [9; 10].

Антропогенное воздействие на флору повсеместно приводит к росту числа адвентивных растений, в связи с чем адвентивная фракция является наиболее динамичным компонентом флоры. Адвентивная фракция флоры Студенческого сквера насчитывает 
29 видов, относящихся к 28 родам и 18 семействам, и составляет 30,9\% флоры. Причём 17 адвентивных видов $(58,6 \%)$ являются культивируемыми интродуцентами, что вполне ожидаемо для сквера, а остальные - сорными растениями (за исключением Polygonum $\times$ arenastrum Boreau, относимого к степному ценотическому элементу).

Как следует из таблицы 4, по времени заноса преобладают кенофиты - 22 вида $(75,9 \%)$. Произрастание большинства из них в сквере связано прямо или косвенно с деятельностью человека: почти $2 / 3$ кенофитов являются эргазиофитами или эргазиофигофитами. Археофиты представлены плюризональными видами, происходящими из средиземноморской и ирано-туранской флористических областей - древних центров земледелия. К археофитам относятся: Capsella bursa-pastoris (L.) Medik., Fumaria officinalis L., Polygonum $\times$ arenastrum Boreau, Sisymbrium loeselii L., Sonchus oleraceus L., Veronica persica Poir., Viola arvensis Murr. - все они являются ксенофитами.

Таблица 4 - Структура адвентивной фракции флоры Студенческого сквера

\begin{tabular}{|l|l|c|c|c|c|c|c|}
\hline \multirow{2}{*}{$\begin{array}{c}\text { Способ } \\
\text { миграции }\end{array}$} & \multirow{2}{*}{$\begin{array}{c}\text { Время } \\
\text { заноса }\end{array}$} & $\begin{array}{c}\text { Эфемеро- } \\
\text { фиты }\end{array}$ & $\begin{array}{c}\text { Колоно- } \\
\text { фиты }\end{array}$ & $\begin{array}{c}\text { Эпеко- } \\
\text { фиты }\end{array}$ & $\begin{array}{c}\text { Агриоэпе- } \\
\text { кофиты }\end{array}$ & $\begin{array}{c}\text { Агрио- } \\
\text { фиты }\end{array}$ & $\begin{array}{c}\text { Все- } \\
\text { го }\end{array}$ \\
\hline \multirow{2}{*}{ Ксенофиты } & Aрхеофиты & - & - & 6 & 1 & - & 7 \\
\hline \multirow{2}{*}{ Ксеноэргазиофигофиты } & Кенофиты & - & - & 3 & 1 & 1 & 5 \\
\hline \multirow{2}{*}{ Эргазиофигофиты } & Археофиты & - & - & - & - & - & - \\
\cline { 2 - 9 } & Кенофиты & - & - & 1 & 2 & - & 3 \\
\hline \multirow{2}{*}{ Эргазиофиты } & Археофиты & - & - & - & - & - & - \\
\cline { 2 - 9 } & Кенофиты & - & 1 & 2 & 3 & 1 & 7 \\
\hline Всего & Археофиты & - & - & - & - & - & - \\
\cline { 2 - 9 } & Кенофиты & 4 & 3 & - & - & - & 7 \\
\hline
\end{tabular}

По степени натурализации видов адвентивная фракция флоры сквера характеризуется преобладанием стабильного компонента - эпекофитов, агриоэпекофитов и агриофитов - 72,4\% от общего числа адвентивных видов. Это свидетельствует о слабых миграционных процессах и устойчивости фитоценоза.

Флорогенетический анализ продемонстрировал преобладание североамериканских растений - 31\% (или 9 видов), что объясняется сходными природноклиматическими условиями обитания данных видов. Как следствие, половина из них является сорными рудеральными видами (Amaranthus blitoides S. Wats., Acer negundo L., Conyza canadensis L., Lepidotheca suaveolens (Pursh) Nutt., Xanthoxalis stricta (L.) Small) другая - культивируемыми интродуцентами (Fraxinus pennsylvanica Marsh., Picea pungens Engelm., Tagetes patula L., Thuja occidentalis L.). Далее следуют ирано-туранские виды - $21 \%$ (или 6 видов), в основном все сорные, затем восточноазиатские (4 вида: Berberis thunbergii DC, Malus baccata (L.) Borkh., Pentaphylloides fruticosa (L.) Schwarz, Spiraea media Schmidt) и сибирские растения (3 вида: Lonicera tatarica L., Sorbaria sorbifolia (L.) A.Br., Swida alba (L.) Opiz.), представленные культивируемыми видами. Также во флоре присутствуют выходцы из Средиземноморья, Западной и Центральной Европы, Центральной Азии.

\section{Выводы}

Территория Студенческого сквера испытывает значительный антропогенный прессинг, отражающийся во флористических параметрах: незначительная доля однодольных, низкое систематическое разнообразие, большой процент видов 10 ведущих семейств и их порядок, высокий индекс синантропизации, соответствующие экологические спектры с преобладанием растений открытых типов местообитаний и сорных видов. Несмотря на это, зелёные насаждения Студенческого сквера находятся в удовлетворительном состоянии и успешно выполняют свои функции, чему благоприятствуют хорошие эда- фические условия. В адвентивной фракции флоры сквера преобладают: 1) кенофиты $(75,9 \%), 2)$ виды, связанные с целенаправленной хозяйственной деятельностью человека $(48,3 \%), 3)$ эпекофиты и агриоэпекофиты $(65,5 \%), 4)$ североамериканские $(31 \%)$ и ирано-туранские $(20,7 \%)$ виды. Помимо текущего ухода за сквером, требуется восстановление отдельных участков газона, либо сильно разреженного (под кронами деревьев, у игровой и спортивной площадок), либо представленного преимущественно сорными растениями. Полученные результаты могут быть использованы при реализации программы «Формирование комфортной городской среды», а также в мониторинге озеленённых территорий общего пользования г. Чебоксары и обновлении паспорта Студенческого сквера, составленного в 2009 г.

\section{СПИСОК ЛИТЕРАТУРЫ:}

1. Постановление администрации города Чебоксары от 24.05.2017 № 1286 «О внесении изменения в постановление администрации города Чебоксары от 30.12.2013 № 4439» [Электронный ресурс] // Официальный сайт Управления ЖКХ, энергетики, транспорта и связи Администрации г. Чебоксары. http://gov.cap.ru/UserFiles/orgs/GovId_798/postanovleni e_ot_24.05.2017_№_1286_podprogramma_formirovani e_sovremennoj_gorodskoj_sredi.doc.

2. Авдеева Е.В., Вагнер Е.А., Надемянов В.Ф., Шмарин Н.В. Городские скверы - их роль в озеленении городов. (На примере исторического развития, обеспеченности и состояния скверов г. Красноярска) // Хвойные бореальной зоны. 2016. Т. XXXIV, № 12. C. $7-15$.

3. Репецкая А.И., Парфенова И.А. Сквер 70-летия Великой Отечественной войны (Севастополь): современное состояние и проектные предложения // Экосистемы. 2015. Вып. 1. С. 41-52.

4. Молганова Н.А., Овеснов С.А. Деревья и кустарники скверов Дзержинского и Мотовилихинского районов г. Перми // Вестник Пермского университета. 2015. Вып. 4. С. 305-316. 
5. Потапова Е.В., Зелинская Е.В. Состояние озеленённых территорий категории общего пользования г. Рязани // Вестник Тверского государственного университета. Серия «Биология и экология». 2016. № 1. С. $142-149$.

6. Гудзенко Е.О., Гудзенко И.И. Анализ современного состояния различных скверов города Ростова-на-Дону // Актуальные проблемы лесного комплекса. 2012. № 33. С. 119-122.

7. Димитриев Ю.О., Куприянова М.Ю. Проблемы эколого-флористического мониторинга урбанизированных территорий // Успехи современного естествознания. 2013. № 7. С. 161-163.

8. Димитриев Ю.О., Алексеева Е.П. Эколого-флористическая оценка сквера Студенческий города Чебоксары Чувашской Республики // Трешниковские чтения - 2017: Современная географическая картина мира и технологии географического образования: матлы всерос. науч.-практ. конф. / под ред. Н.А. Ильиной, Е.А. Артемьевой, В.Н. Федорова и др. Ульяновск: УлГПУ им. И.Н. Ульянова, 2017. С. 116-118.

9. Димитриев Ю.О., Гаврилова Т.В. Флора сквера им. М. Горького города Чебоксары Чувашской Республики // Научное обозрение. Биологические науки. 2017. № 1. С. 87-90.

10. Димитриев Ю.О., Гаврилова Т.В. Эдафотопическая структура флоры сквера им. М. Горького города Чебоксары Чувашской Республики // Биоэкологическое краеведение: мировые, российские и региональные проблемы: мат-лы 5-й междунар. науч.практ. конф., посв. 110-летию со дня рождения доктора биологических наук, профессора Л.В. Воржевой и 125 -летию со дня рождения кандидата педагогических наук, доцента Г.Г. Штехера. 14 декабря 2016 г., г. Самара, Российская Федерация / отв. ред. С.И. Павлов. Самара: СГСПУ, 2016. С. 68-70.

11. Димитриев Ю.О., Грошева Л.Г. О флоре сквеpa им. К.В. Иванова города Чебоксары Чувашской Республики // Любищевские чтения - 2017. Современные проблемы экологии и эволюции: сборник материалов всерос. (с междунар. уч.) науч. конф. (Ульяновск, 30-31 марта 2017 г.). Ульяновск: УлГПУ им. И.Н. Ульянова, 2017. С. 173-178.

12. Димитриев Ю.О., Грошева Л.Г. Флористическое обследование сквера им. К.В. Иванова города
Чебоксары Чувашской Республики // Культура, наука, образование: проблемы и перспективы: мат-лы VI междунар. науч.-практ. конф. (г. Нижневартовск, 1315 февраля 2017 года). Нижневартовск: Изд-во Нижневарт. гос. ун-та, 2017. Ч. ІІ. Естественные и технические науки. С. 15-18.

13. Маевский П.Ф. Флора средней полосы европейской части России. М.: Товарищество научных изданий КМК, 2014. 635 с.

14. Шадрин В.А. Флористические параметры в оценке синантропизации флоры // Сравнительная флористика на рубеже III тысячелетия: достижения, проблемы, перспективы: мат-лы рабочего совещания по сравнительной флористике (Ижевск, 1998 г.). СПб.: БИН РАН, 2000. С. 288-300.

15. Гафурова М.М. Сосудистые растения Чувашской Республики. Флора Волжского бассейна. Т. III. Тольятти: Кассандра, 2014. 333 с.

16. Березуцкий М.А., Панин А.В. Флора городов: структура и тенденции антропогенной динамики // Ботанический журнал. 2007. Т. 92, № 10. С. 14811490.

17. Восточноевропейские леса: история в голоцене и современность: В 2 кн. Кн. 1 / отв. ред. О.В. Смирнова. М.: Наука, 2004. 479 с.

18. Димитриев Ю.О. Эколого-ценотический анализ парциальных флор города Ульяновска // Вестник Чувашского государственного педагогического университета им. И.Я. Яковлева. 2014. № 4 (84). C. 57-62.

19. Прокопьев Е.П., Рыбина Т.А., Амельченко В.П., Мерзлякова И.Е. Современное состояние флоры и растительности Университетской рощи и возможные пути её реконструкции в будущем // Вестник Томского государственного университета. Биология. 2009. № 2 (6). С. $29-41$.

20. Виноградова Ю.К., Майоров С.Р., Хорун Л.В. Чёрная книга флоры Средней России (Чужеродные виды растений в экосистемах Средней России): учебное пособие. М.: ГЕОС, 2009. 494 с.

21. Матвеев Н.М. Оптимизация системы экоморф растений А.Л. Бельгарда в целях фитоиндикации экотопа и биотопа // Вісник Дніпропетровського університету. Біологія, екологія. 2003. Т. 2, вып. 11. C. $105-113$.

\title{
FLORA OF THE STUDENT SQUARE OF CHEBOKSARY OF CHUVASH REPUBLIC
}

(C) 2017

\author{
Dimitriev Yury Olegovich, candidate of biological sciences, \\ associate professor of Bioecology and Chemistry Department \\ I. Yakovlev Chuvash State Pedagogical University (Cheboksary, Russian Federation)
}

Abstract. Student Square was opened on September 1, 2007 at the intersection of the busy Moscow Avenue and K. Ivanov Street. The total area is 2,5 hectares. The predominant tree species are Tilia cordata Mill., Betula pendula Roth and Acer platanoides L. In 2016, the first inventory of the square flora was carried out, 94 plant species from 79 genera and 37 families were identified. Pinopsida are represented by 4 cultivated introducents. Only 6 species from the Poaceae are monocotyledons. The systematic diversity of the flora is very low. Virtually every genus is represented by only one species. The average level of species wealth in one family is 2,54 . The number of families with one species is $21(56,8 \%)$. The top ten in the number of species families are concentrated by $63,8 \%$ of the species. The spectrum of the leading families of the flora of the Student Square indicates its thermophilic appearance. The share of synanthropic species in the flora as a whole is $53,2 \%$. The index of synanthropization (Is) of the square flora is 1,14 and emphasizes the anthropogenic nature of the landscape. The aboriginal fraction of the flora is strongly altered $(I s=0,48)$. In the ecologo-cenotic spectrum, there is a preponderance towards plants of open habitat types, among which weed species predominate (34\%), among which 4 are malignant invasive species: Acer negundo L., Conyza canadensis (L.) Cronq., Lepidotheca suaveolens (Pursh) Nutt., Xanthoxalis stricta (L.) Small. On the second 
place is a group of meadow plants $(16 \%)$. The distribution of other coenotic groups in general is consistent with the regional spectrum of the flora of Chuvashia. The hygromorph spectrum is dominated by mesophytes $(71,3 \%)$, followed by xeromesophytes $(16 \%)$, the share of the remaining groups varies from 1,1 to $6,4 \%$. The trofomorph spectrum is dominated by mesotrofs $(62,8 \%)$ and megatrofs $(36,2 \%)$. Aliens fraction is $30,9 \%$ of the square flora. 17 species $(58,6 \%)$ are cultivated introducents, and the rest - weed plants. Kenophytes $(75,9 \%)$ predominate, ergasiophytes and ergasiofigophytes $(24,1 \%$ each), epekophytes and agrio-epekophytes (65,5\%), North American (31\%) and Iranian-Turanian $(20,7 \%)$ species.

Keywords: flora; square; gardening; Cheboksary; Chuvash Republic; comfortable urban environment; environmental assessment; taxonomic analysis; synanthropization; ecologo-cenotic spectrum; invasive plants; hygromorphs; trofomorphs; non-native (aliens) plants; florogenetic analysis.

УДК 581. 9 (476)

Статья поступила в редакцию 02.08.2017

\section{ОСОБЕННОСТИ СТРУКТУРЫ ЦЕНОПОПУЛЯЦИЙ ПОЛЫНИ СОЛЯНКОВИДНОЙ (ARTEMISIA SALSOLOIDES WILLD., ASTERACEAE) В САМАРСКОЙ ОБЛАСТИ}

Зенкина Татьяна Евгеньевна, кандидат биологических наук, начальник отдела экологии; старший преподаватель кафедры биологии

Волгограднефтепроект (г. Волгоград, Российская Федераџия);

Волгоградский государственный университет (г. Волгоград, Российская Федераџия)

Ильина Валентина Николаевна, кандидат биологических наук, доцент кафедры биологии, экологии и методики обучения

Самарский государственный соџиально-педагогический университет (г. Самара, Российская Федераџия)

Аннотация. Полынь солянковидная (Artemisia salsoloides Willd., Asteraceae) включена в Красные книги России и различных регионов, в том числе Самарской области. Характеризуется узкой приуроченностью к эколого-фитоценотическим условиям местообитаний. Нами изучена структура популяций вида. Использованы традиционные стационарные методы изучения ценотических популяций. Оценка пространственной структуры была выполнена с использованием современных математических методов, выполнен расчёт $K(r)$ функции Рипли и кросс-функции Рипли. Охарактеризованы фитогенные поля видов, произрастающих совместно с A. salsoloides. Территория исследований включает Самарское Предволжье и Заволжье. В усреднённом возрастном спектре преобладающей группой является зрелая генеративная, чуть уступает по численности особей старая генеративная фракция. Динамика популяций флуктуационная. Изучены особенности пространственного размещения особей A. salsoloides в популяции на Серноводском Шихане (Сергиевский район Самарской области). Здесь полынь является доминантом в составе сообщества Artemisia salsoloides Willd. + Hedysarum grandiflorum Pall. - Stipa korshinskyi Roshev. Плотность A. salsoloides в изученной ценопопуляции

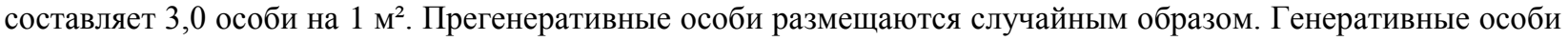
отталкиваются друг от друга на расстояние 0,2 м с последующим случайным размещением. Есть тенденция к образованию агрегаций размером 0,6 м. Оценка взаимного размещения A. salsoloides и Stipa korshinskyi, a также Oxytropis floribunda показывает на незначимое отталкивание особей на расстояние 0,2 м, с Hedysarum grandiflorum - значимое отталкивание на расстояние 0,4 м (с последующим случайным размещением у всех представителей). У особей A. salsoloides и Ephedra distachya, а также Scabiosa isetensis отмечено случайное размещение.

Ключевые слова: Artemisia salsoloides Willd; ценопопуляция; онтогенетическая структура; базовый онтогенетический спектр; редкий вид; антропогенный фактор; растительное сообщество; степи; пространственная структура; функция Рипли; кросс-функция Рипли; локальная плотность; размещение особей; отталкивание особей; агрегация; случайное размещение; фитогенное поле; коэффициент напряженности фитогенного поля; Самарская область; Серноводский Шихан.

\section{Введение}

Объектом нашего изучения послужила полынь солянковидная (Artemisia salsoloides Willd., Asteraceaе). Это восточноевропейско-южносибирский полукустарник, петрофит, кальцефил, включенный в Красные книги РФ [1] и различных регионов [2-4]. Популяционная организация вида изучается в различных регионах [5], в том числе в Волгоградской и Самарской областях [6-10]. Основными видами воздействия на сообщества с участием модельного вида являются нерегламентированный выпас скота, степные пожоги, рекреация. Многие популяции A. Salsoloides в Самарской области находятся в угнетенном состоянии и отличаются низкими показателями виталитета.

\section{Методы исследования}

В ходе работ использовались традиционные методы изучения ценопопуляций [11-13]. Выявлены особенности онтогенетической структуры и пространственного размещения растений в сообществах. Оценка пространственной структуры была выполнена с использованием современных математических методов [14-16]. Выполнялся расчет $K(r)$ функции Рипли $[17 ; 18]$ и осуществлялось построение карт локальной плотности с помощью метода бегущего или скользящего окна (moving window) [19] на основе ядерных функций kernel (kernel function) [20; 21]. Для удобства анализа результат представлялся графически в виде функции $L(r)-r$, где $L(r)=\sqrt{ } K(r) / \pi$ [22]. Для анализа пространственных закономерностей 